IZA DP No. 5009

School Shootings and Student Performance

Panu Poutvaara

Olli Ropponen

June 2010 


\title{
School Shootings and Student Performance
}

\author{
Panu Poutvaara \\ University of Helsinki \\ and IZA
}

Olli Ropponen

University of Helsinki

\section{Discussion Paper No. 5009 \\ June 2010}

IZA

P.O. Box 7240

53072 Bonn

Germany

Phone: +49-228-3894-0

Fax: +49-228-3894-180

E-mail: iza@iza.org

Any opinions expressed here are those of the author(s) and not those of IZA. Research published in this series may include views on policy, but the institute itself takes no institutional policy positions.

The Institute for the Study of Labor (IZA) in Bonn is a local and virtual international research center and a place of communication between science, politics and business. IZA is an independent nonprofit organization supported by Deutsche Post Foundation. The center is associated with the University of Bonn and offers a stimulating research environment through its international network, workshops and conferences, data service, project support, research visits and doctoral program. IZA engages in (i) original and internationally competitive research in all fields of labor economics, (ii) development of policy concepts, and (iii) dissemination of research results and concepts to the interested public.

IZA Discussion Papers often represent preliminary work and are circulated to encourage discussion. Citation of such a paper should account for its provisional character. A revised version may be available directly from the author. 
IZA Discussion Paper No. 5009

June 2010

\section{ABSTRACT}

\section{School Shootings and Student Performance*}

In this paper, we study how high school students reacted to the shocking news of a school shooting. The shooting coincided with national high-school matriculation exams. As there were exams both before and after the shooting, we can perform a difference-in-differences analysis to uncover how the school shooting affected the test scores compared to previous years. We find that the average score of young men declined due to the school shooting, whereas we do not observe a similar pattern for women.

JEL Classification: $\quad$ C21, J16, I19

Keywords: school shootings, school performance, shocking news, gender differences, treatment effect models

Corresponding author:

Panu Poutvaara

Department of Economics

Arkadiankatu 7 (P.O. Box 17)

00014 University of Helsinki

Finland

E-mail: panu.poutvaara@helsinki.fi

\footnotetext{
* We are grateful for helpful comments to Niclas Berggren, Henrik Jordahl, Katarina Keller, Minna Magnusson, Janne Tukiainen, and participants at the HECER lunch seminar in Helsinki and the CESifo Employment and Social Protection Area Conference in Munich. We thank the Matriculation Examination Board for providing us the data, without implicating them for the conclusions we draw.
} 


\section{Introduction}

In recent years, the United States and several European countries have suffered from a number of school shootings. In addition to the tragic direct consequences for the victims and their families, school shootings, much like terrorist attacks, may dominate news for days, having a traumatic effect on millions of other people. Lynn A. Addington (2003) uses National Crime Victimization Survey data to explore the effects of the Columbine High School Shooting on students' fear, finding that students were slightly more fearful afterwards. ${ }^{1}$ Sandro Galea et al. (2002) document that the 9/11 terrorist attack resulted in thousands of New York City residents developing posttraumatic stress disorder, and William E. Schlenger et al. (2002) showed that this was also the case in other parts of the United States. Edward B. Blanchard et al. (2005) found that the college-age population in the United States still suffered from the 9/11 attacks in the fall 2002, with a larger effect in cities closer to New York City. Their findings indicate that traumatic news may have a long-lasting influence.

Finland has witnessed two school shootings in recent years, both of which received wide media coverage. The first one took place in November 2007 in Jokela in Southern Finland, and the second one in September 2008 in Kauhajoki in Western Finland. We focus on the second shooting as it coincided with national high-school matriculation exams. ${ }^{2}$ As some of the tests took place before the shooting and others after, we can perform a difference-in-differences (DID) analysis to uncover how the school shooting affected the test scores. Our treatment group consists of tests that took place in 2008 after the shooting, and the control group of tests that took place before. We first calculate for each gender how performance changed in comparison to the previous or an earlier year in both of these groups. Comparing the change in the treatment group to the one in the control group gives us an estimate for the effect of the school shooting on student performance.

We study the reactions of men and women separately, as previous research has documented various gender differences. Women are found to suffer more often from acute and posttraumatic stress disorder (see Murray B. Stein et al. 1997; Galea et al. 2002; Schlenger et al. 2002; Roxane Cohen Silver et al. 2002; Randall D. Marshall et al. 2007; Rajiv Jhangiani 2010). This suggests that women would also respond to the school shooting more strongly. On the other hand, there is a vast literature (see Kathryn E. Grant et al. (2006)) showing that social support protects young people from the negative

\footnotetext{
${ }^{1}$ Columbine High School shooting was the biggest U.S. news story in 1999 as measured by Cable News Network (CNN) ratings. Glenn W. Muschert (2009) explored the subsequent media dynamics, finding that the news coverage focused first on what happened in Columbine, and then moved to repercussions across the country.

${ }^{2}$ We do not analyze the effects of the 2007 school shooting, as it took place after that year's fall semester examinations.
} 
effects of stressors (a buffering effect). Kenneth S. Kendler, John Myers, and Carol A. Prescott (2005) find that women have, on average, wider social networks than men. This suggests an opposite gender pattern: wider social networks could give women more protection against the adverse effects of the shocking news. There is extensive evidence on gender differences also in other contexts both in psychological and economic literature (Alice H. Eagly 1995; Stein et al. 1997; Francine D. Blau and Lawrence M. Kahn 2000; Grant et al. 2006; Rachel Croson and Uri Gneezy 2009).

Using DID analyses, we find that the average examination results of young men declined due to the shooting, whereas we do not observe a similar pattern for women. To test for gender differences in reactions to the school shooting, we present a difference-in-difference-in-differences (DDD) analysis. The performance of men declines more than the performance of women in all specifications. This difference is statistically significant in two out of four specifications.

The school shooting in 2008 took place at the Seinäjoki University of Applied Sciences. Universities of applied sciences provide bachelor-level education, and are a common choice after high school. Some of the students taking their matriculation exams may have thought that if the shooting had taken place a couple of years later, they might have been among the victims. In addition, the Kauhajoki shooting may have reactivated tragic memories from the previous year shooting in the Jokela region. ${ }^{3}$

We study separately the effects of the school shooting in the region in which it occurred, in the region in which the first school shooting had taken place, and in the rest of the country. We analyze the Jokela region separately in order to avoid the risk that the results for the rest of the country would be driven by possible reactivation of painful memories among those who had lost a relative or friend in the previous shooting.

Most of the previous research on the psychological aftermath of shocking news has relied on survey data (see Galea et al. 2002; Schlenger et al. 2002; Silver et al. 2002; Mohammad R. Torabi and Dong-Chul Seo 2004; Blanchard et al. 2005; Galea and Heidi Resnick 2005). ${ }^{4}$ Collecting such data

\footnotetext{
${ }^{3}$ Jennifer Ahern et al. (2002) find that exposure to graphic television images of the 9/11 terrorist attacks increased the risk of posttraumatic stress disorder among those who were directly affected by the attacks, for example by having a friend killed.

${ }^{4}$ An intriguing exception is the analysis by Jenny C. Su et al. (2009) who document that the Northeast of the United States exhibited a significant increase in traffic fatalities in general and those involving alcohol or drugs in particular in the last quarter of 2001. Their hypothesis is that increased stress after the $9 / 11$ terrorist attack decreased driving quality.
} 
could trigger traumatic memories, especially among those who reacted to the events most strongly. ${ }^{5}$ Another important challenge with survey data is commensurability: respondents with the same symptoms may classify their severity differently. ${ }^{6}$ A further challenge in using data from the health care services is that many of those who need mental help do not seek it. Our analysis measures responses to shocking news using standardized test scores. As we have results for all students in a random sample of schools, we avoid problems related to sample selection, as well as under- or overreporting of symptoms in surveys.

Previous research related to school shootings has been devoted to the personality and background of perpetrators (Peter Langman 2009; James P. McGee and Caren R. DeBernando 1999; J. Reid Meloy et al. 2001), factors predicting school shootings (Mary Ellen O’Toole 2000; Stephanie Verlinden, Michel Hersen and Jay Thomas 2000), the cultural content in which school shootings take place (Doreen Arcus 2002; Michael S. Kimmel and Matthew Mahler 2003), and the fear of victimization following school shootings (Addington 2003; Clete Snell et al. 2002; Paul B. Stretesky and Michael J. Hogan 2001). Vicky Curry (2003) examines the psychological effect of a school shooting in the community in which it occurred. ${ }^{7}$

Our paper is related to an increasing strand of literature that examines the direct consequences of terrorist attacks and natural disasters, or uses such events as exogenous source of variation to examine some other question. Previous papers have examined the psychological aftermath of natural disasters (Greg Miller 2005; Cynthia L. Rowe and Howard A. Liddle 2008) or terrorist attacks (Ahern et al. 2002; Blanchard et al. 2005; Jonathan Laugharne, Alexander Janca and Thomas Widiger 2007; Marshall et al. 2007; Jhangiani 2010; Ughetta Moscardino et al. 2010), exploited exogenous variation in police presence that was caused by terrorist attacks or the threat thereof to study the effects of policing on crime (Rafael Di Tella and Ernesto Schargrodsky 2004; Jonathan Klick and Alexander Tabarrok 2005; Panu Poutvaara and Mikael Priks 2009), or studied the labor market consequences of forced migration (Jeffrey A. Groen and Anne E. Polivka 2008; see also Christina Paxson and Cecilia Elena Rouse 2008).

\footnotetext{
${ }^{5}$ Research on the effects of terrorism, school shootings, natural disasters and other traumatic events raises serious ethical questions. As our study uses register data, the risk of burdening the victims is minimal, and meets the guidelines set in the meeting entitled "Ethical Issues Pertaining to Research in the Aftermath of Disaster" that was sponsored by the New York Academy of Medicine and the National Institute of Mental Health; see Lauren K. Collogan et al. (2004).

${ }^{6}$ Silver (2004) provides an excellent overview of the challenges associated with conducting methodologically rigorous studies of responses to traumatic experiences.

${ }^{7}$ For excellent summaries of research on school shootings, see Muschert (2009) and Traci L. Wike and Mark W. Fraser (2009).
} 
Our paper proceeds as follows. Section 2 provides background information on Finnish matriculation examinations and the school shooting. Section 3 describes the data and the empirical framework. Section 4 presents the results. It starts by describing the development of interruption rates, continues with statistics on the average performance, and ends with an econometric analysis. Section 5 concludes.

\section{National Matriculation Exams and the School Shooting}

In Finland, every student who wants to graduate from high school has to pass matriculation exams in at least four subjects, one of which has to be the mother tongue (Finnish, Swedish or Sami) ${ }^{8}$. The tests are administered nationally at the same time in each school, with the same questions and grading criteria in the whole country. In each spring and fall, there is an exam period of two to three weeks. Students have to pass the required tests over three consecutive exam periods. Each test can be taken only on a given day and students have to register for their chosen tests several months in advance. On most of the exam days there are separate tests in different subjects.

In the fall of 2008, the exam period took place from September 12 until October 1. On September 23, a lone gunman murdered nine students and one employee in Kauhajoki at Seinäjoki University of Applied Sciences, before committing suicide. By that time, 18 out of 38 tests had already taken place. This massacre, which took place in the middle of the exam period, dominated the news for several days. We examine the effects of shocking news by comparing the average of the test scores after the shooting to the ones in the same subjects in previous years. In order to control for possible cohort differences, we also perform a similar analysis for tests that took place before the shooting.

\section{Data and Empirical Framework}

The Matriculation Examination Board, which is responsible for organizing the matriculation exams, has kindly provided us with test results in the years 2006, 2007 and 2008 in seven schools of the Kauhajoki region where the 2008 shooting took place, in eight schools of the Jokela region where the 2007 shooting took place, and in 40 randomly selected schools in the rest of the country. In total, there are 470 high schools in Finland, of which our sample includes about 12 percent. We use test

\footnotetext{
${ }^{8}$ Sami is a small language that is spoken by the indigenous Sami people in Lapland. There were 4 students taking the Sami exam in the fall of 2006 and 2008, and 6 students in the fall of 2007. None of them are in our sample.
} 
results for the fall only, to account for systematic differences in participation and performance between fall and spring periods. Table 1 reports the sample sizes. There we divide tests into the group "before" that includes tests that took place in 2008 before the shooting and into the group "after" for tests that took place after.

\section{Table 1 here}

The choice of the years in the analysis is driven by two important reforms in the matriculation examination. The biggest reform in decades took place in 2006. Before the reform, there had been separate tests only for Finnish, Swedish, Sami, foreign languages, and mathematics. In addition, there was a joint test for sciences and humanities, including biology, chemistry, geography, history, physics, psychology, and others. Since 2006, all subjects have had their own separate tests. This reform rules out the possibility of comparing average test scores after 2006 with pre-2006 figures. In 2007, the grading criteria for the tests in mother tongue were changed. Additionally, a test on health education was introduced. We perform two different comparisons: between 2006 and 2008, and between 2007 and 2008. When comparing 2006 and 2008, the tests in mother tongue and health education are excluded, due to the 2007 reform. Using both 2006 and 2007 as comparison years reduces the risk that eventual results would be driven by outliers in test performance in 2006 or 2007.

In the analysis we first employ the DID estimation separately for men and women to capture the effect of the shooting on the average performance. The equation we estimate is

$y_{i j t}=\beta_{0}+\beta_{1} A_{i j}+\beta_{2} T_{i t}+\beta_{3} A_{i j} T_{i t}+\beta_{4} X_{i j t}+\varepsilon_{i j t}$,

where $y_{i j t}$ is the standardized test score of student $i$ in subject $j$ in year $t, \beta_{0}$ is a constant, $A_{i j}$ is a dummy variable for the subject that takes value one if the test took place in 2008 after the shooting, $T_{i t}$ is a dummy variable for the year 2008, $A_{i j} T_{i t}$ is the interaction term, $X_{i j t}$ includes the control variables and $\varepsilon_{i j t}$ is the error term. The corresponding equation in the DDD estimation is

$y_{i j t}=\beta_{0}+\beta_{1} M_{i}+\beta_{2} A_{i j}+\beta_{3} T_{i t}+\beta_{4} M_{i} A_{i j}+\beta_{5} M_{i} T_{i t}+\beta_{6} A_{i j} T_{i t}+\beta_{7} M_{i} A_{i j} T_{i t}+\beta_{8} X_{i j t}+\varepsilon_{i j t}$,

where $M_{i}$ is a dummy variable for male. 
Finland has two official languages, Finnish, which is spoken as the mother tongue by 92 percent of the population, and Swedish, which is spoken by 6 percent. Both school shootings took place in Finnish-speaking communities. To account for possible differences, we also clustered the sampling by language. Of the 40 schools outside the Jokela and Kauhajoki regions, 33 were Finnish-speaking and 7 Swedish-speaking. In the Kauhajoki region, one school was Swedish-speaking, and in the Jokela region none. We first present our results for Finnish-speaking and Swedish-speaking schools together, including a language dummy as a control variable in all regressions in sections 4.3 and 4.4. We then report the results according to the mother tongue in section 4.5. We also clustered the sampling by whether the high school is a day school or an evening school. Students in evening schools are usually somewhat older. Our sample includes 13 Finnish-speaking and 2 Swedish-speaking evening schools. We present results for day schools and evening schools together, but all qualitative results hold also if the analysis is restricted to day schools.

\section{Results}

\subsection{Interruptions}

In Table 2, we report the percentage of tests that were interrupted in 2006, 2007 and 2008 in the Kauhajoki region, the Jokela region, and the rest of the country. There are no statistically significant changes in the interruption rates in the group "after" in 2008 in the rest of the country. ${ }^{9}$ The only statistically significant effect is among women in the Kauhajoki region who interrupted their tests more often after the shooting when compared with the year 2006. In the Jokela region the interruption rate increased more among men, but this change is not statistically significant.

Table 2 here

\subsection{Average Performance}

We measure individual performance on a test as the percentage of the theoretical maximum points. We first examine how the average test score developed over the years 2006, 2007 and 2008, again separately for tests that took place in 2008 before the shooting, and for those that took place after it.

\footnotetext{
${ }^{9}$ We have tested the statistical significance of the changes in the interruptions by using a DID analysis with the same covariates as in tables 4 and 5 below. The results are available upon request.
} 
Table 3 reports the average performance in 2006, 2007 and 2008 where mother tongue and health education are excluded, due to the reform in $2007 .^{10}$

The changes in the average performance outside Jokela and Kauhajoki regions are striking. The average test score in exams that took place before the shooting was the same in 2007 and 2008 for both men and women with a one-decimal precision. In the exams after the shooting, the average test score of men dropped by 3.5 percentage points, and that of women by 2.2 percentage points. Therefore, men appear to react more strongly.

The results related to the average test scores are not as clear for the Jokela and Kauhajoki regions. In both regions, the performance of men deteriorated after the shooting when 2007 is used as the reference year. If 2006 is used as reference year, we do not find such an effect. For women, we find a small decrease in the performance after the shooting when 2007 is used as a reference year. When 2006 is used as reference year, performance declines quite similarly in exams before and after the shooting, so we find no evidence of an effect from the shooting. As the interruption rate of women somewhat increased in the Kauhajoki region after the shooting, as reported in Table 2, their DID result concerning the average performance has to be interpreted with caution. If those who would perform worse than average are also more likely to interrupt their exams, then an increased interruption rate could mask the drop in performance among women in the Kauhajoki region.

Table 3 here.

\subsection{The Effects outside the Jokela and Kauhajoki Regions}

In order to account for possible gender differences in responses to traumatic news of the school shooting, we carry out the DID analysis separately for men and women. We first analyze all subjects together. After that, we carry out an analysis of a balanced sample where we drop the three subjects with most exam participants (English, Finnish and Swedish), in order to reduce the effects of year-toyear variation in the level of difficulty of any single test.

\footnotetext{
${ }^{10}$ Taking an average of individual performances corresponds in our case to taking a weighted average of average performances on different exams, with weights corresponding to the number of participants.
} 
In Table 4, we present the DID analysis for men outside the Jokela and Kauhajoki regions. The first two columns use data from the years 2006 and 2008 and the two last ones from 2007 and 2008. The estimated treatment effect is negative, independently of whether we use the year 2006 or 2007 and all subjects or just the balanced sample. The effect is statistically significant at the 5-percent level, apart from the specification using the year 2006 and not using a balanced sample. We control for whether the test took place in evening schools or Swedish-speaking schools as well as whether the test was compulsory. ${ }^{11}$

Table 4

In Table 5, we present the corresponding analysis for women. The DID estimate is close to zero when comparing the years 2007 and 2008, and positive but statistically insignificant when comparing the years 2006 and 2008. ${ }^{12}$ Therefore, we do not find evidence for the hypothesis that the performance of women would have deteriorated outside the Jokela and Kauhajoki regions after the school shooting.

Table 5

To test whether the gender difference in tables 4 and 5 is statistically significant, we have also performed a DDD analysis. In Table 6, we present those results in a way that the DDD estimate reveals how men reacted, compared to women. ${ }^{13}$ We find that the performance of men declined more after the school shooting than that of women. The difference is statistically significant at the 5-percent level when comparing performances between 2006 and 2008.

Table 6

We have also performed an analysis corresponding to tables 4 to 6 with school fixed effects. All results remain qualitatively the same.

\footnotetext{
${ }^{11}$ The examination consists of at least four tests. One of them, the test in the candidate's mother tongue, is compulsory for all candidates. The candidate then chooses three other compulsory tests from among the following four alternatives: mathematics; Finnish or Swedish as second national language; one foreign language test; one test in sciences or humanities. All compulsory tests have to be passed within three consecutive exam periods. As part of his or her examination, the candidate may additionally include one or more optional tests.

${ }^{12}$ The DID estimate in the fourth column is 0.04 .

${ }^{13}$ Female DID estimate in the fourth column is -0.00009 .
} 


\subsection{The Effects in the Jokela and Kauhajoki Regions}

Our prior was that the news of the school shooting would have reactivated negative memories of the tragedy in the previous year more vividly in the Jokela region than outside Jokela and Kauhajoki regions, resulting in a bigger negative shock. We did not find any support for this hypothesis. ${ }^{14}$

The results for the Kauhajoki region, in which the shooting took place, should not be directly compared with the results from outside Jokela and Kauhajoki regions, where the effects are driven by the shock resulting from the news. In the Kauhajoki region, some exam participants may have lost a family member or friend in the school shooting, or known some of the victims or the perpetrator. Surprisingly, the estimated effects in the Kauhajoki region are weaker than in the rest of the country, and not statistically significant. The negative effect seems to show up among women as an increase in the interruption rate. The DID estimate for Kauhajoki women is 4.8 and statistically significant ${ }^{15}$ when comparing the years 2006 and 2008, and 3.7 and not statistically significant when comparing the years 2007 and 2008.

\subsection{Reactions According to Language Division}

To examine whether Finnish-speakers and Swedish-speakers reacted differently, we performed separate analyses according to the main language of the school. We find a negative effect for men among both Finnish-speakers and Swedish-speakers, and no effect for Finnish-speaking women. For Swedish-speaking women, the average performance in 2008 decreased more before than after the shooting. As a consequence, the estimated treatment effect is positive and statistically significant when all exams are included, and insignificant and of varying sign in the balanced sample. ${ }^{16}$ To sum up: Our main conclusion that men reacted negatively to school shooting holds for both Finnish-speakers and Swedish-speakers. We do not find evidence that the performance of women would have declined as a response to the shooting.

\footnotetext{
${ }^{14}$ Regression results for the Jokela and Kauhajoki regions are available upon request. Even if there is no sign of the presumed bigger negative shock in the analysis of the performance, this may show up for Jokela men in the form of a slight increase in the interruption rate. For men the DID estimates for interruption rates in the Jokela region are 4.1 and 3.5 when comparing the year 2008 to 2006 and 2007 respectively (see table 2). For women the corresponding estimates are 2.2 and 1.1. Estimates are positive for both men and women, but statistically insignificant.

${ }^{15}$ With a p-value 0.0144 .

${ }^{16}$ Regression results are available upon request.
} 
Bruce D. Meyer (1995) lists potential threats to both internal and external validity of studies using natural experiments. Most of the potential concerns, like omitted variables, trends in outcomes, misspecified variances and mismeasurement, should not affect our results.

Omitted variables should not drive our results for two reasons. First, we include in the regressions all the explanatory variables that are present in the data, and are statistically significant in explaining the performance. Second, if there was some omitted variable, its effect on the estimation results should be negligible as we examine the same control and treatment groups of tests in each year, and perform DID and DDD analyses. If there were any differences between various tests driven by an omitted variable in 2008, then they should also show up in 2006 and in 2007. To control for the possibility of trends in outcomes, we have performed corresponding analyses for springs (available upon request). None of the pseudo-treatments have statistically significant effects, suggesting that there are no trends in outcomes. Theoretically, the fact that we observe several test results for most participants suggests that error terms should be clustered at the individual level. In practice, the fact that we have thousands of observations with just a few on each of the individuals indicates that the effect of the clustering of the variance should not play any significant role in our study. It also seems unlikely that our study would suffer from mismeasurement of the variables, because there have not been any changes in the definitions of variables. Furthermore, the tests have been planned by the Matriculation Examination Board in order to provide a reliable performance measure, which would serve as a nationwide standardized test.

Attrition, resulting in differential loss of respondents in the treatment and control groups, corresponds in our case to interrupting a test, or not showing up, and can be viewed as an outcome variable of interest in itself. The fact that there are more interruptions among Kauhajoki women due to the incident can be viewed as an additional evidence of a negative impact of the shooting.

\section{Conclusion}

In this paper, we have examined how students' performance changed due to the shocking news of a school shooting. We analyzed the effect separately in the region in which the shooting took place, in the region that had suffered from a school shooting the previous year, and in the rest of the country. Our main result is that the performance of men declined due to the school shooting outside the Jokela 
and Kauhajoki regions. For women, we did not find any systematic effect, with point estimates varying in signs. However, the interruption rate increased for women in the Kauhajoki region in which the shooting took place.

Our analysis suggests several topics for further research. First of all, our analysis of short-term effects calls for a complementary analysis of long-term effects. Secondly, it would be interesting to study responses to news of a school shooting in different age groups; in our sample, most people were aged 18 to 20 . Thirdly and finally, data from other countries, if available, would allow testing for eventual cross-country differences.

\section{References}

Addington, Lynn A. 2003. "Students' Fear after Columbine: Findings from a Randomized Experiment." Journal of Quantitative Criminology, 19: 367-387.

Ahern Jennifer, Sandro Galea, Heidi Resnick, Dean Kilpatrick, Michael Bucuvalas, Joel Gold and David Vlahov. 2002. "Television Images and Psychological Symptoms after the September 11 Terrorist Attacks." Psychiatry: Interpersonal and Biological Processes, 65: 289-300.

Arcus, Doreen. 2002. "School Shooting Fatalities and School Corporal Punishment: A Look at the States." Aggressive Behavior, 28: 173-183.

Blanchard, Edward B., Dianna Rowell, Eric Kuhn, Rebecca Rogers and David Wittrock. 2005. "Posttraumatic stress and depressive symptoms in a college population one year after the September 11 attacks: the effect of proximity." Behaviour Research and Therapy, 43: 143-150.

Blau, Francine D. and Lawrence M. Kahn. 2000. "Gender Differences in Pay." Journal of Economic Perspectives, 14 (4): 75-99.

Collogan, Lauren K., Farris Tuma, Regina Dolan-Sewell, Susan Borja and Alan R. Fleischman. 2004. "Ethical Issues Pertaining to Research in the Aftermath of Disasters." Journal of Traumatic Stress, 17: 363-372.

Croson, Rachel and Uri Gneezy. 2009. "Gender Differences in Preferences." Journal of Economic Literature, 47: 448-474.

Curry, Vicky. 2003. "Thurston High School: The Effects of Both Distal and Emotional Proximity in an Acute Instance of School Violence." Journal of School Violence, 2: 93-120.

Di Tella, Rafael and Ernesto Schargrodsky. 2004. "Do Police Reduce Crime? Estimates Using the Allocation of Police Forces After a Terrorist Attack." American Economic Review, 94:115-33.

Eagly, Alice H. 1995. "The Science and Politics of Comparing Women and Men." American Psychologist, 50: 145-158. 
Galea, Sandro, Jennifer Ahern, Heidi Resnick, Dean Kilpatrick, Michael Bucuvalas, Joel Gold and David Vlahov. 2002. "Psychological Sequelae of September 11 Terrorist Attacks in New York City." New England Journal of Medicine, 346: 982-987.

Galea, Sandro and Heidi Resnick. 2005. "Posttraumatic Stress Disorder in the General Population After Mass Terrorist Incidents: Considerations About the Nature of Exposure." CNS Spectrums, 10: 107-115.

Grant, Kathryn E., Bruce E. Compas, Audrey E. Thurm, Susan D. McMahon, Polly Y. Gipson, Amanda J. Campbell, Kimberly Krochock and Robert I. Westerholm. 2006. "Stressors and child and adolescent psychopathology: Evidence of moderating and mediating effects." Clinical Psychology Review, 26: 257-283.

Groen, Jeffrey A. and Anne E. Polivka. 2008. "The Effect of Hurricane Katrina on the Labor Market Outcomes of Evacuees." American Economic Review: Papers and Proceedings, 98: 43-48.

Jhangiani, Rajiv. 2010. "Psychological Concomitants of the 11 September 2001 Terrorist Attacks: A Review." Behavioral Sciences of Terrorism and Political Aggression, 2: 38-69.

Kendler, Kenneth S., John Myers and Carol A. Prescott. 2005. "Sex Differences in the Relationship Between Social Support and Risk for Major Depression: A Longitudinal Study of Opposite-Sex Twin Pairs." American Journal of Psychiatry, 162: 250-256.

Kimmel, Michael S. and Matthew Mahler. 2003. "Adolescent Masculinity, Homophobia, and Violence: Random School Shootings, 1982-2001.” American Behavioral Scientist, 46: 1439-1458.

Klick, Jonathan and Alexander Tabarrok. 2005. "Using Terror Alert Levels to Estimate the Effect of Police on Crime.” Journal of Law and Economics, 68: 267-279.

Langman, Peter. 2009. "Rampage School Shooters: A Typology." Aggression and Violent Behavior, 12: 79-86.

Laugharne, Jonathan, Aleksandar Janca and Thomas Widiger. 2007. "Posttraumatic Stress Disorder and Terrorism: 5 Years after 9/11." Current Opinion in Psychiatry, 20: 36-41.

Marshall, Randall D., Richard A. Bryant, Lawrence Amsel, Eun Jung Suh, Joan M. Cook and Yuval Neria. 2007. "The Psychology of Ongoing Threat: Relative Risk Appraisal, the September 11 Attacks, and Terrorism-Related Fears." American Psychologist, 62: 304-316.

McGee, James P. and Caren R. DeBernardo. 1999. "The Classroom Avenger: A Behavioral Profile of School Based Shootings.” The Forensic Examiner, 8: 16-18.

Meloy, J. Reid, Anthony G. Hempel, Kris Mohandie, Andrew A. Shiva and Thomas Gray. 2001. "Offender and Offense Characteristic of a Nonrandom Sample of Adolescent Mass Murderers." Journal of the American Academy of Child and Adolescent Psychiatry, 40: 719-728.

Meyer, Bruce D. 1995. "Natural and Quasi-Experiments in Economics.”Journal of Business and Economic Statistics, 13: 151-161. 
Moscardino, Ughetta, Sara Scrimin, Fabia Capello and Gianmarco Altoe. 2010. "Social Support, Sense of Community, Collectivistic Values, and Depressive Symptoms in Adolescent Survivors of the 2004 Beslan Terrorist Attack." Social Science and Medicine, 70: 27-34.

Miller, Greg. 2005. “The Tsunami’s Psychological Aftermath.” Science, 425: 1030-1033.

Muschert, Glenn W. 2009. "Frame-changing in the Media Coverage of a School Shooting: The Rise of Columbine as a National Concern." Social Science Journal, 46: 164-170.

O’Toole, Mary Ellen 2000. "The School Shooter: A Threat Assessment Perspective." Quantico VA: Critical Incident Response group, National Center for the Analysis of Violent Crime, FBI Academy.

Paxson, Christina and Cecilia Elena Rouse. 2008. "Returning to New Orleans after Hurricane Katrina." American Economic Review: Papers and Proceedings, 98: 38-42.

Poutvaara, Panu and Mikael Priks. 2009. "The Effect of Police Intelligence on Group Violence: Evidence from Reassignments in Sweden." Journal of Public Economics, 93: 403-411.

Rowe, Cynthia L. and Howard A. Liddle. 2008. "When the Levee breaks: Treating Adolescents and Families in the Aftermath of Hurricane Katrina." Journal of Marital and Family Therapy, 34: 132148.

Schlenger, William E., Juesta M. Caddell, Lori Ebert, B. Kathleen Jordan, Kathryn M. Rourke, David Wilson, Lisa Thalji, J. Michael Dennis, John A. Fairbank and Richard A. Kulka. 2002. "Psychological Reactions to Terrorist Attacks: Findings from the National Study of Americans' Reaction to September 11." Journal of the American Medical Association, 5: 581-588.

Silver, Roxane Cohen. 2004. "Conducting Research After 9/11 Terrorist Attacks: Challenges and Results." Families, Systems and Health, 22: 47-51.

Silver, Roxane Cohen, E. Alison Holman, Daniel N. McIntosh, Michael Poulin and Virginia GilRivas. 2002. "Nationwide Longitudinal Study of Psychological Responses to September 11." Journal of American Medical Association, 288: 1235-1244.

Snell, Clete, Charles Bailey, Anthony Corona and Dalila Mebane. 2002. "School Crime Policy Changes: The Impact of Recent Highly-Publicized School Crimes." American Journal of Criminal Justice, 26: 269-285.

Stein, Murray B., John R. Walker, Andrea L. Hazen and David R. Forde. 1997. "Full and Partial Posttraumatic Stress Disorder: Findings From a Community Survey." American Journal of Psychiatry, 154: 1114-1119.

Su, Jenny C., Alisia G.T.T. Tran, John G. Wirtz, Rita A. Langteau and Alexander J. Rothman. 2009. "Driving Under the Influence (of Stress): Evidence of a Regional Increase in Impaired Driving and Traffic Fatalities After the September 11 Terrorist Attacks." Psychological Science, 20: 59-65.

Stretesky, Paul B. and Michael J. Hogan. 2001. "Columbine and Student Perceptions of Safety: A Quasi-Experimental Study.” Journal of Criminal Justice, 29: 429-443. 
Torabi, Mohammad R. and Dong-Chul Seo. 2004. "National Study of Behavioral and Life Changes Since September 11." Health Education and Behavior, 31: 179-192.

Verlinden, Stephanie, Michel Hersen and Jay Thomas. 2000. "Risk Factors in School Shootings." Clinical Psychology Review, 29: 3-56.

Wike, Traci L. and Mark W. Fraser. 2009. "School Shootings: Making Sense of the Senseless." Aggression and Violent Behavior, 14: 162-169. 
Table 1: Sample sizes

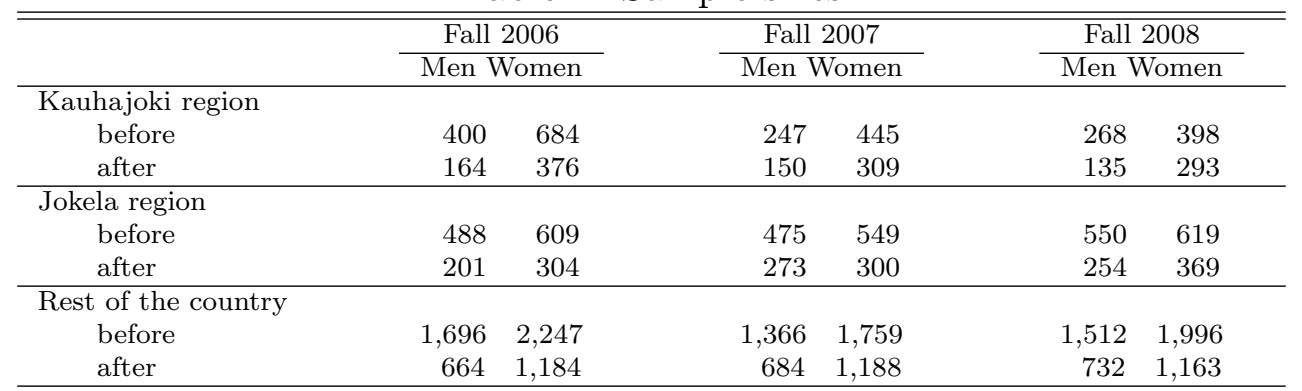


Table 2: Percentages of interrupted tests

\begin{tabular}{|c|c|c|c|}
\hline & $\begin{array}{c}\text { Fall } 2006 \\
\text { Men Women }\end{array}$ & $\begin{array}{c}\text { Fall } 2007 \\
\text { Men Women }\end{array}$ & $\begin{array}{c}\text { Fall } 2008 \\
\text { Men Women }\end{array}$ \\
\hline \multicolumn{4}{|c|}{ Kauhajoki region } \\
\hline before & 4.8 & 3.8 & 4.8 \\
\hline after & 3.7 & 2.0 & 3.0 \\
\hline \multicolumn{4}{|c|}{ Jokela region } \\
\hline before & 4.4 & 6.0 & 4.5 \\
\hline after & 3.5 & 4.8 & 7.1 \\
\hline \multicolumn{4}{|c|}{ Rest of the country } \\
\hline before & 7.0 & 5.9 & 6.8 \\
\hline after & 4.4 & 7.3 & 6.1 \\
\hline
\end{tabular}

Notes: Mother tongue and health education are excluded. 
Table 3: Standardized average performances

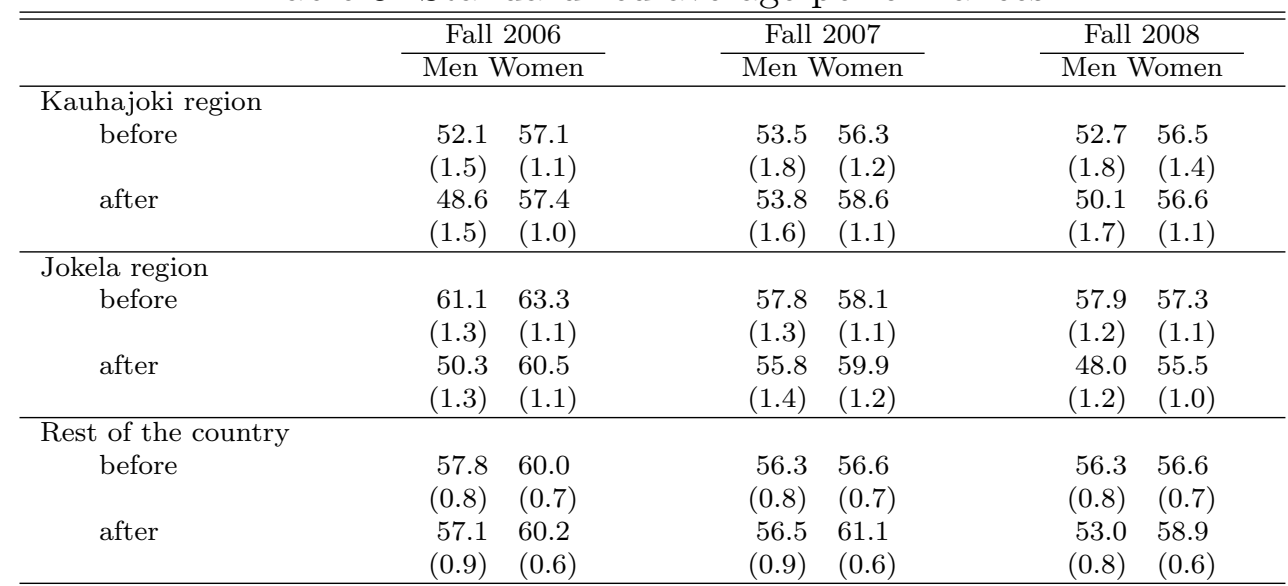

Notes: Mother tongue and health education are excluded. Standard errors are given in parenthesis. 
Table 4: DID estimation results for men

\begin{tabular}{|c|c|c|c|c|}
\hline & \multicolumn{2}{|c|}{2006 and 2008} & \multicolumn{2}{|c|}{2007 and 2008} \\
\hline & $\begin{array}{l}\text { all tests } \\
\text { (1) }\end{array}$ & $\begin{array}{l}\text { balanced } \\
\text { sample } \\
(2)\end{array}$ & $\begin{array}{l}\text { all tests } \\
\text { (3) }\end{array}$ & $\begin{array}{l}\text { balanced } \\
\text { sample } \\
(4)\end{array}$ \\
\hline After & -1.6 & $5.7^{* * *}$ & $2.8^{*}$ & $5.3^{* * *}$ \\
\hline Fall 2008 & $\begin{array}{l}(1.2) \\
-1.5 \\
(1.0)\end{array}$ & $\begin{array}{c}(1.5) \\
0.9 \\
(1.3)\end{array}$ & $\begin{array}{l}(1.1) \\
-0.4 \\
(0.9)\end{array}$ & $\begin{array}{c}(1.4) \\
1.0 \\
(1.2)\end{array}$ \\
\hline After $*$ Fall 2008 (DID estimate) & $\begin{array}{l}-2.2 \\
(1.6)\end{array}$ & $\begin{array}{l}-5.2^{*} \\
(2.0)\end{array}$ & $\begin{array}{l}-3.2^{*} \\
(1.5)\end{array}$ & $\begin{array}{l}-4.4^{*} \\
(1.9)\end{array}$ \\
\hline Evening school & $\begin{array}{c}-14.2^{* * *} \\
(1.0)\end{array}$ & $\begin{array}{c}-11.8^{* * *} \\
(1.3)\end{array}$ & $\begin{array}{c}-13.3^{* * *} \\
(0.9)\end{array}$ & $\begin{array}{c}-12.2^{* * *} \\
(1.2)\end{array}$ \\
\hline Swedish school & $\begin{array}{l}13.8^{* * *} \\
(1.1)\end{array}$ & $\begin{array}{c}2.1 \\
(1.9)\end{array}$ & $\begin{array}{l}9.9^{* * *} \\
(1.9)\end{array}$ & $\begin{array}{c}0.6 \\
(1.8)\end{array}$ \\
\hline Non-obligatory & $\begin{array}{l}-1.7 \\
(1.2)\end{array}$ & $\begin{array}{l}10.7^{* * *} \\
(1.3)\end{array}$ & $\begin{array}{c}0.4 \\
(1.1)\end{array}$ & $\begin{array}{l}11.0^{* * * *} \\
(1.2)\end{array}$ \\
\hline Evening school * Non-obligatory & $\begin{array}{c}4.4 \\
(3.2)\end{array}$ & $\begin{array}{c}2.1 \\
(3.3)\end{array}$ & $\begin{array}{c}0.3 \\
(3.1)\end{array}$ & $\begin{array}{c}0.4 \\
(3.0)\end{array}$ \\
\hline Swedish school * Non-obligatory & $\begin{array}{c}-15.4^{* * *} \\
(2.9)\end{array}$ & $\begin{array}{l}-4.7 \\
(3.3)\end{array}$ & $\begin{array}{c}-15.0^{* * *} \\
(2.8)\end{array}$ & $\begin{array}{l}-9.2^{* *} \\
(3.1)\end{array}$ \\
\hline Constant & $\begin{array}{l}59.6^{* * *} \\
(0.8)\end{array}$ & $\begin{array}{l}39.9 * * * \\
(1.1)\end{array}$ & $\begin{array}{l}54.9^{* * *} \\
(0.7)\end{array}$ & $\begin{array}{l}39.9^{* * * *} \\
(1.0)\end{array}$ \\
\hline Observations & 3,395 & 1,675 & 4,027 & 1,858 \\
\hline
\end{tabular}

Notes: The dependent variable is standardized performance. The results are for men outside Kauhajoki and Jokela regions. Columns (1) and (2) use the data for falls 2006 and 2008 and exclude the data for mother tongue and health education. Columns (3) and (4) use the data for falls 2007 and 2008. Swedish schools are those where the mother tongue is Swedish. In the balanced sample case the estimation results are derived from the data without English, Finnish and Swedish. Standard errors are given in parentheses. $(*),(* *)$ and $(* * *)$ correspond to $5 \%, 1 \%$ and $0.1 \%$ risk levels respectively. 
Table 5: DID estimation results for women

\begin{tabular}{|c|c|c|c|c|}
\hline & \multicolumn{2}{|c|}{2006 and 2008} & \multicolumn{2}{|c|}{2007 and 2008} \\
\hline & $\begin{array}{l}\text { all tests } \\
\text { (1) }\end{array}$ & $\begin{array}{c}\text { balanced } \\
\text { sample } \\
(2)\end{array}$ & $\begin{array}{l}\text { all tests } \\
\text { (3) }\end{array}$ & $\begin{array}{c}\text { balanced } \\
\text { sample } \\
(4)\end{array}$ \\
\hline After & $\begin{array}{c}0.6 \\
(0.9)\end{array}$ & $\begin{array}{l}4.4^{* * *} \\
(1.3)\end{array}$ & $\begin{array}{l}6.0^{* * *} \\
(0.8)\end{array}$ & $5.3^{* * *}$ \\
\hline Fall 2008 & $\begin{array}{l}-3.3^{* * *} \\
(0.8)\end{array}$ & $\begin{array}{l}-1.5 \\
(1.2)\end{array}$ & $\begin{array}{l}-1.2 \\
(0.7)\end{array}$ & $\begin{array}{c}0.7 \\
(1.0)\end{array}$ \\
\hline After * Fall 2008 (DID estimate) & $\begin{array}{c}2.3 \\
(1.2)\end{array}$ & $\begin{array}{c}1.5 \\
(1.8)\end{array}$ & $\begin{array}{l}-0.4 \\
(1.1)\end{array}$ & $\begin{array}{c}0.0 \\
(1.6)\end{array}$ \\
\hline Evening school & $\begin{array}{c}-15.0^{* * *} \\
(0.8)\end{array}$ & $\begin{array}{c}-15.0^{* * * *} \\
(1.2)\end{array}$ & $\begin{array}{c}-15.1^{* * *} \\
(0.7)\end{array}$ & $\begin{array}{c}-14.1^{* * *} \\
(1.1)\end{array}$ \\
\hline Swedish school & $\begin{array}{l}11.8^{* * *} \\
(0.9)\end{array}$ & $\begin{array}{c}0.4 \\
(1.8)\end{array}$ & $\begin{array}{l}9.5^{* * *} \\
(0.8)\end{array}$ & $\begin{array}{c}2.0 \\
(1.4)\end{array}$ \\
\hline Non-obligatory & $\begin{array}{l}-3.8^{* * *} \\
(0.9)\end{array}$ & $\begin{array}{l}7.8^{* * *} \\
(1.1)\end{array}$ & $\begin{array}{l}-3.9^{* * * *} \\
(0.8)\end{array}$ & $\begin{array}{l}6.7^{* * * *} \\
(1.0)\end{array}$ \\
\hline Evening school * Non-obligatory & $\begin{array}{l}10.0^{* * *} \\
(2.3)\end{array}$ & $\begin{array}{l}10.9^{* * * *} \\
(2.6)\end{array}$ & $\begin{array}{l}10.2^{* * *} \\
(2.0)\end{array}$ & $\begin{array}{l}9.3^{* * *} \\
(2.3)\end{array}$ \\
\hline Swedish school $*$ Non-obligatory & $\begin{array}{c}-12.3^{* * *} \\
(2.2)\end{array}$ & $\begin{array}{l}-4.2 \\
(2.9)\end{array}$ & $\begin{array}{c}-12.0^{* * *} \\
(1.8)\end{array}$ & $\begin{array}{l}6.4^{* *} \\
(2.3)\end{array}$ \\
\hline Constant & $\begin{array}{l}62.0^{* * *} \\
(0.6)\end{array}$ & $\begin{array}{l}46.5^{* * *} \\
(1.0)\end{array}$ & $\begin{array}{l}57.5^{* * *} \\
(0.6)\end{array}$ & $\begin{array}{l}45.4^{* * *} \\
(0.9)\end{array}$ \\
\hline Observations & 4,798 & 2,143 & 5,857 & 2,632 \\
\hline
\end{tabular}

Notes: The dependent variable is standardized performance. The results are for women outside

Kauhajoki and Jokela regions. Columns (1) and (2) use the data for falls 2006 and 2008 and exclude the data for mother tongue and health education. Columns (3) and (4) use the data for falls 2007 and 2008. Swedish schools are those where the mother tongue is Swedish. In the balanced sample case the estimation results are derived from the data without English, Finnish and Swedish. Standard errors are given in parentheses. $(*),(* *)$ and $(* * *)$ correspond to $5 \%, 1 \%$ and $0.1 \%$ risk levels respectively. 
Table 6: DDD estimation results for men and women

\begin{tabular}{|c|c|c|c|c|}
\hline & \multicolumn{2}{|c|}{2006 and 2008} & \multicolumn{2}{|c|}{2007 and 2008} \\
\hline & $\begin{array}{l}\text { all tests } \\
\text { (1) }\end{array}$ & $\begin{array}{l}\text { balanced } \\
\text { sample } \\
(2)\end{array}$ & $\begin{array}{l}\text { all tests } \\
(3)\end{array}$ & $\begin{array}{c}\text { balanced } \\
\text { sample } \\
(4)\end{array}$ \\
\hline Male & -1.8 & $-5.1^{* * *}$ & $-1.8^{*}$ & $-4.5^{* * *}$ \\
\hline & $(0.9)$ & $(1.3)$ & $(0.8)$ & $(0.8)$ \\
\hline After & 0.5 & $4.3^{* * *}$ & $5.9^{* * *}$ & $5.1^{* * *}$ \\
\hline & $(0.9)$ & $(1.3)$ & $(0.8)$ & $(1.2)$ \\
\hline Fall 2008 & $-3.3^{* * *}$ & -1.5 & -1.1 & 0.7 \\
\hline & $(0.9)$ & $(1.2)$ & $(0.7)$ & $(1.0)$ \\
\hline Male $*$ After & -1.9 & 1.4 & $-2.8^{*}$ & 0.5 \\
\hline & $(1.4)$ & $(2.0)$ & $(1.3)$ & $(1.8)$ \\
\hline Male * Fall 2008 & 1.8 & 2.5 & 0.8 & 0.2 \\
\hline & $(1.3)$ & $(1.8)$ & $(1.1)$ & $(1.5)$ \\
\hline After ${ }^{*}$ Fall 2008 (Female DID estimate) & $\begin{array}{c}2.3 \\
(1.3)\end{array}$ & $\begin{array}{c}1.6 \\
(1.8)\end{array}$ & $\begin{array}{l}-0.4 \\
(1.2)\end{array}$ & $\begin{array}{c}-0.0 \\
(1.6)\end{array}$ \\
\hline Male ${ }^{*}$ After ${ }^{*}$ Fall 2008 (DDD estimate) & $\begin{array}{l}-4.6^{*} \\
(2.0)\end{array}$ & $\begin{array}{l}-6.8^{*} \\
(2.7)\end{array}$ & $\begin{array}{l}-2.7 \\
(1.8)\end{array}$ & $\begin{array}{l}-4.3 \\
(2.5)\end{array}$ \\
\hline Evening school & $\begin{array}{l}-14.7^{* * *} \\
(0.6)\end{array}$ & $\begin{array}{r}-13.5 \\
(0.9)\end{array}$ & $\begin{array}{c}-14.4^{* * *} \\
(0.5)\end{array}$ & $\begin{array}{c}-13.3^{* * *} \\
(0.8)\end{array}$ \\
\hline Swedish school & $\begin{array}{l}12.7^{* * *} \\
(0.7)\end{array}$ & $\begin{array}{c}1.1 \\
(1.3)\end{array}$ & $\begin{array}{l}9.7^{* * * *} \\
(0.6)\end{array}$ & $\begin{array}{c}1.5 \\
(1.1)\end{array}$ \\
\hline Non-obligatory & $\begin{array}{l}-3.0^{* * *} \\
(0.7)\end{array}$ & $\begin{array}{l}9.0^{* * *} \\
(0.8)\end{array}$ & $\begin{array}{l}-2.2^{* * *} \\
(0.6)\end{array}$ & $\begin{array}{l}8.4^{* * *} \\
(0.7)\end{array}$ \\
\hline Evening school $*$ Non-obligatory & $\begin{array}{l}7.8^{* * *} \\
(1.9)\end{array}$ & $\begin{array}{l}7.3^{* * *} \\
(2.0)\end{array}$ & $\begin{array}{l}6.5^{* * *} \\
(1.7)\end{array}$ & $\begin{array}{l}5.9^{* *} \\
(1.8)\end{array}$ \\
\hline Swedish school * Non-obligatory & $\begin{array}{c}-13.7^{* * *} \\
(1.8)\end{array}$ & $\begin{array}{l}-4.4^{*} \\
(2.2)\end{array}$ & $\begin{array}{c}-13.3^{* * *} \\
(1.6)\end{array}$ & $\begin{array}{l}-7.5^{* * *} \\
(1.8)\end{array}$ \\
\hline Constant & $\begin{array}{l}61.8^{* * *} \\
(0.6)\end{array}$ & $\begin{array}{l}45.9^{* * *} \\
(0.9)\end{array}$ & $\begin{array}{l}57.1^{* * *} \\
(0.6)\end{array}$ & $\begin{array}{l}45.0^{* * *} \\
(0.8)\end{array}$ \\
\hline Observations & 8,193 & 3,818 & 9,884 & 4,490 \\
\hline
\end{tabular}

Notes: The dependent variable is standardized performance. The results are for men and women outside Kauhajoki and Jokela regions. Columns (1) and (2) use the data for falls 2006 and 2008 and exclude the data for mother tongue and health education. Columns (3) and (4) use the data for falls 2007 and 2008. Swedish schools are those where the mother tongue is Swedish. In the balanced sample case the estimation results are derived from the data without English, Finnish and Swedish. Standard errors are given in parentheses. $(*),(* *)$ and $(* * *)$ correspond to $5 \%, 1 \%$ and $0.1 \%$ risk levels respectively. 